DOI:10.17951/h.2021.55.3.37-50

\begin{tabular}{lcc}
\hline \multicolumn{3}{c}{ A N N A L E S } \\
UNIVERSITATIS MARIAE CURIE-SKŁODOWSKA \\
LUBLIN - POLONIA \\
VOL. LV, 3 & SECTIOH H \\
\hline
\end{tabular}

\author{
LENA GRZESIAK \\ lena.grzesiak@uni.lodz.pl \\ University of Łódź. Faculty of Management \\ 22/26 Matejki St., 90-237 Łódź, Poland \\ ORCID ID: https://orcid.org/0000-0001-5078-1675
}

\title{
An Internal Audit Expectation Gap in Poland
}

Keywords: internal audit expectation gap; opinion survey; internal audit effectiveness; internal audit expectation; Poland

JEL: M21; M42; M49

How to quote this paper: Grzesiak, L. (2021). An Internal Audit Expectation Gap in Poland. Annales Universitatis Mariae Curie-Skłodowska, sectio H-Oeconomia, Vol. 55, No. 3.

\footnotetext{
Abstract

Theoretical background: One of the factors influencing internal audit effectiveness is the expectation gap understood as the extent to which the function does not meet the expectations of auditees, managers, executives, and audit committee members.

Purpose of the article: The purpose of the article was to determine why they perceive internal audit in their organisations as not fulfilling their expectations and how their awareness of this affects internal audit effectiveness.

Research methods: This article is a pilot study that uses the results of a critical review of the literature and the findings of the survey of internal audit stakeholders in Poland.

Main findings: The article shows that internal audit stakeholders have limited knowledge of the role and responsibilities of internal auditors and the purpose of their work. According to their views, the raison d'etre of the internal audit function is fraud detection. This perception of internal audit that emerged in its early years still determines the majority of opinions about its effectiveness.
} 


\section{Introduction}

Driven by individuals' hopes and desires as to the outcomes of activities, expectations influence the way people behave and make decisions (Filipczyk-Gałązka, 1994, p. 21; Kozielecki, 1997, p. 79). They can be broadly divided into explicit expectations (clearly communicated or well-known) and hidden expectations (tacit and elusive). Expectations have a significant effect on audit activity effectiveness. They may increase it by specifying areas in need of intervention and improvement, or reduce it, when they are unrealistic, or, worse still, unethical, and contrary to the International Standards for the Professional Practice of Internal Auditing (2016).

This study of the internal audit expectation gap builds on the author's previous research examining internal audit effectiveness with respect to the human capital of internal auditors, auditees and managers, which demonstrated that internal auditors who took account of stakeholders' expectations and needs were more effective in adding value to their organisations. As a result, they tended to be perceived as more competent and their work as more useful for the organization (Grzesiak, 2020). This observation is consistent with one of the definitions of "internal audit effectiveness", defining it as the extent to which the internal audit results fulfil stakeholders' expectations. It implies, therefore, that the perception of it is primarily determined by subjective, personal judgements (Cohen \& Sayag, 2010, pp. 297-298).

The discrepancy between what audit stakeholders expect from it and what it can deliver is known as the audit expectation gap (Koh \& Woo, 1998, p. 147). According to Dobroțeanu, Dobroțeanu, and Ciolpan (2009, p. 906), the number of international studies dealing with it is substantial, but as most of them use the generic term "audit", it is difficult to determine whether their authors examine it from the perspective of internal audit, external audit, or both. Only frequent references to financial statements revealed by the literature review conducted by the author of this paper suggest that it is the external audit gap that draws the most interest from researchers. The internal audit gap and its effect on internal audit effectiveness is still insufficiently explored, despite rising awareness that internal audit is as vulnerable to the audit expectation gap as external audit. This article, therefore, specifically concentrates on the internal audit expectation gap.

The article was inspired by the author's earlier research on perceived internal audit effectiveness, which showed it to vary depending on the degree to which internal auditors met stakeholders' expectations. Its aim is to present how discrepancies between the expectations of internal audit stakeholders in Poland and internal audit's objectives shape the perception of its effectiveness. Specifically, the article seeks to determine why stakeholders may perceive internal audit and its outcomes as falling short of their expectations and how this disillusionment impacts their judgement of internal audit effectiveness. 
The paper is structured as follows. In section 1, the internal audit expectation and internal audit effectiveness are discussed. Section 2 explains the research methodology and analyses the results obtained. In the concluding section 3 , the discussion of the results and the research limitations and conclusions are provided.

\section{An internal audit expectation gap and internal audit effectiveness}

The word "audit" involves some definitional ambiguity (Moeller, 2018, p. 26), because without a proper qualifier and a context it may refer to external audit, internal audit, or both these activities. The instinctive tendency to understand it as external audit is quite natural, because the original reason for audit to emerge was the need to ensure compliance between mandatory requirements and organisations' financial reporting and accounting policies (Meigs, Whittington, Meigs, \& Lam, 1983, p. 20).

The most widely used definition of internal audit, proposed by the Institute of Internal Auditors (IIA), ${ }^{1}$ describes it as: "an independent, objective assurance and consulting activity designed to add value and improve an organization's operations. It helps an organization accomplish its objectives by bringing a systematic, disciplined approach to evaluate and improve the effectiveness of risk management, control, and governance processes" (International Standards for the Professional Practice of Internal Auditing, 2016). The definition points to various functions that internal audit should perform, among which control, consulting, adding value, and improving organisations' effectiveness are noteworthy because of their direct effect on how organisations fare. Thus, it identifies internal audit as distinctive from external audit and shows how far it has evolved from external audit focused on financial control and financial compliance (Skoczylas-Tworek, 2014, pp. 11-20).

A function created to evaluate the effectiveness of organizational processes must be effective itself. The widening range of tasks allocated to internal audit and growing expectations regarding its usefulness have been followed by a rise in the interest in measuring and evaluating its effectiveness (KPMG, 2016, p. 1). Although relatively detailed, the IIA definition of "internal audit" (IIA, 2011, p. 1) fails to directly explain when internal audit should be deemed effective. In order to bridge the gap, a number of definitions describing internal audit effectiveness have been proposed (Bednarek, 2016, p. 34; Lenz, Sarens, \& Jeppesen, 2018, p. 4). According to one of them, the effectiveness of internal audit should be measured by its ability to achieve its goals and meet the expectations of its key stakeholders. ${ }^{2}$ The second element emphasises

1 The IIA is the oldest and largest international organization of internal auditors. According to its charter, its focus is on training and certifying internal auditors and developing the International Standards for the Professional Practice of Internal Auditing (2016).

2 The literature refers to individuals using internal audit as "internal audit clients" or "internal audit stakeholders". These are primarily auditees, managers, executives, and audit committee members (Skoczylas-Tworek, 2014, p. 240). 
that "non-auditors" and their subjective judgements have a bearing on the perception of internal audit as effective or ineffective (Bednarek, 2016, p. 34).

The needs and expectations regarding internal audit and its results vary between both organisations and stakeholders (Ahmad \& Taylor, 2009, p. 902) and many a time conflict with each other (Arena \& Sarens, 2015, p. 131). In a PwC survey (2016), $62 \%$ of internal audit stakeholders indicated that the function should add value to processes in the organization and boost its performance. For the stakeholders surveyed by Frigo (2002), a measure of internal audit effectiveness was the extent to which it met their needs and expectations. Lenz, Sarens, and Hoos (2017) concluded that the ability of internal audit stakeholders to clearly state their hopes and needs made it easier for internal auditors to deliver on them. Let us recall here that the extent to which internal auditors are capable of catering to the expectations of their stakeholders is significant for how the latter will evaluate their performance and the usability of their findings (effectiveness). Internal auditors who deliberately or inadvertently ignore their stakeholders' expectations are at risk of losing their trust and undermine their position.

Without challenging the above statement about it being necessary for internal auditors to comply with stakeholders' expectations and incorporate them into an internal audit task (D'Onza \& Sarens, 2018, p. 3; IIA, n.d., p. 2, 4), it is important to note that some of the expectations may be self-serving, unrealistic, or unethical. Such expectations cannot be fulfilled unless an internal auditor is ready to breach professional standards and brush aside their duties to the organization. Some authors also express doubts as to internal auditors' ability to cope with all expectations put forward by stakeholders, given their increasing number and complexity (Carcello, Eulerich, Masli, \& Wood, 2018, p. 121). Inadequate or overwhelming expectations of internal audit stakeholders carry the risk of an expectation gap emerging in the organization, which may undermine the status of internal auditors and result in the depreciation of their work (Lenz, Sarens, \& Jeppesen, 2018, p. 12).

The phrase "an audit expectation gap" was coined by Liggio in 1974 (Koh \& Woo, 1998, p. 149) with respect to auditors examining organisations' financial documents and procedures for compliance with mandatory regulations. The number of theoretical and empirical studies on the audit expectation gap has since increased considerably but there are still unanswered questions about the nature and causes of this phenomenon. Table 1 presents several definitional approaches to the audit expectation gap that have been used by researchers as a framework for their investigations.

Excluding Godsell's definition, the other three definitions in Table 1 refer to financial statements, implying that their authors created them with external audit in mind. There are two more definitions that are worth mentioning here because they go beyond the financial perspective. Humphrey, Moizer, and Turley (1993) described the audit expectation gap as "a representation of the feeling that auditors are performing in a manner at variance with the beliefs and desires of those for whose benefit the 
audit is carried out". A similar perspective was adopted by Porter (1993), ${ }^{3}$ who defined it "as the gap between society's expectations of auditors and auditors' performance, as perceived by society" (as quoted in: Koh \& Woo, 1998, p. 147).

Table 1. Selected definitions of the "audit expectation gap" (emphasis added)

\begin{tabular}{|l|l|}
\hline Author & Definition \\
\hline Ojo (2009) & $\begin{array}{l}\text { "the difference between what the users of financial statements perceive an audit to be } \\
\text { and what the audit profession claim is expected of them in conducting an audit" }\end{array}$ \\
\hline AICPA (1993) & $\begin{array}{l}\text { "the difference between what the public and financial statement users believe auditors } \\
\text { are responsible for and what auditors themselves believe their responsibilities are" }\end{array}$ \\
\hline Godsell (1992) & $\begin{array}{l}\text { "it [audit expectation gap - L.G] is said to exist, when auditors and the public hold dif- } \\
\text { ferent beliefs about the auditors' duties and responsibilities and the messages conveyed } \\
\text { by audit reports" }\end{array}$ \\
\hline Liggio (1974, p. 27) & $\begin{array}{l}\text { "the difference between the levels of expected performance as envisioned by the inde- } \\
\text { pendent accountant and by the user of financial statements" }\end{array}$ \\
\hline
\end{tabular}

Source: Author's own study based on (Dewing \& Russel, 2002, p. 537; Koh \& Woo, 1998, pp. 147-148).

The foregoing section can be summed as follows. An internal audit expectation gap may be caused by a number of factors, including distrust in the internal audit profession, excessive expectations of internal audit stakeholders, communication errors between them and internal auditors, and, paradoxically, internal auditing standards, which require auditors to ignore unethical expectations (Enes, de Almeida, da Silva, Carvalho, \& Simões, 2016, pp. 10-11; Koh \& Woo, 1998, p. 150, 152; Ruhnke \& Schmidt, 2014, p. 573; Porter, 1993). Research has provided evidence that the adverse impact of the expectation gap on the credibility and prestige of the profession of internal auditors and internal audit effectiveness is proportional to its width (Sikka et al., 1998, as quoted in: Azham, Teck Heang, Mohamad, \& Ojo, 2008 , p. 69). As it seems, the expectation gap may not only cause internal audits to be less effective but also contribute to stakeholders perceiving them as ineffective.

\section{Research method}

This article is based on the findings of a pilot study which was carried out to better understand the research problem, to find the optimal ways of exploring it (cf. Nowak, 2007, pp. 58-61), and to create a solid base for future research in the absence of Polish studies on the internal audit expectations gap.

The pilot study involved an online survey of a group of internal audit stakeholders (auditees, managers/executives and audit committee members). This research method was adopted for two main reasons. Firstly, it is convenient to apply and allows opinions to be promptly collected from a large group of respondents. Secondly, as long as the questions

\footnotetext{
3 According to Porter $(1990,1993)$, an audit expectation gap consists of the reasonableness gap and the performance gap.
} 
are clearly framed, it ensures relative reliability and objectivity of the results by preventing the interviewer from influencing, voluntarily or involuntarily, respondents' answers.

The questionnaire was prepared in the Polish and English languages following a critical review of studies on the audit expectation gap and internal audit effectiveness. Part 1 of the questionnaire had 4 questions concerning respondents' demographic characteristics and part 2 contained 17 single-choice questions and 4 multiple-choice questions asking the respondents about their opinions, feelings, knowledge, perceptions, and expectations about internal audit in their organisations. In order to test their familiarity with internal audit, some questions were provided with a mixture of correct answers and distractors referring to widespread myths and stereotypes surrounding the function (cf. Grzesiak, 2019). The questionnaire also provided the respondents with the option to give answers other than proposed by the author, but none of them chose to exercise it.

Between December 2020 and February 2021, links to the survey questionnaire were sent to around 200 internal audit stakeholders employed by general government sector and private organisations with internal audit departments by mail or via LinkedIn. Approximately one-fourth of them (57) consented to participate and returned completed questionnaires.

The characteristics of the respondents are presented in Table 2.

Table 2. Characteristics of respondents

\begin{tabular}{|l|l|r|}
\hline \multirow{3}{*}{ Education } & higher & 34 \\
\cline { 2 - 3 } & secondary & 19 \\
\cline { 2 - 3 } & elementary & 2 \\
\hline \multirow{2}{*}{ Sex } & male & 32 \\
\cline { 2 - 3 } & female & 25 \\
\hline \multirow{4}{*}{ Status } & managers/executives & 25 \\
\cline { 2 - 3 } & auditees & 11 \\
\cline { 2 - 3 } & audit committee members & 54 \\
\hline \multirow{2}{*}{$\begin{array}{l}\text { Completed training in internal } \\
\text { audit for non-internal auditors }\end{array}$} & no & 3 \\
\cline { 2 - 3 } & yes & 25 \\
\hline
\end{tabular}

Source: Author's own study.

In order to account for the diversity of the respondents, their answers were grouped for analysis according to respondents' level of education, gender, status (in relation to internal audit), and participation in internal audit training for non-internal auditors. Regarding the education structure, most respondents (34) were higher education graduates, one-third (19) had secondary education, and 2 completed primary schools. The ratio between males and females in the group was 32 to 25. The largest subgroup were managers and executives (32) followed by auditees (25), and audit committee members (11). Only 3 respondents had been in internal audit training for non-auditors. None of the respondents was an internal auditor nor was professionally involved in internal audit activity. 


\section{Results}

The respondents' answers in Tables 3-10 are arranged according to their frequency. Because the occurrence of an internal audit expectation gap is attributed to poor comprehension of internal audit and misunderstandings surrounding internal auditors' responsibilities, the respondents were first requested to rate their knowledge of internal audit and to state whether they wanted to learn more about it (Table 3 ).

Table 3. How would you rate your knowledge of internal audit?

\begin{tabular}{|l|l|c|}
\hline \multicolumn{1}{|c|}{ Question } & \multicolumn{1}{|c|}{ Answer } & Total \\
\hline \multirow{4}{*}{$\begin{array}{l}\text { How much do you know about internal } \\
\text { audit? }\end{array}$} & enough & 51 \\
\cline { 2 - 3 } & no answer & 4 \\
\cline { 2 - 3 } & little & 2 \\
\cline { 2 - 3 } & I don't know & 50 \\
\hline \multirow{2}{*}{$\begin{array}{l}\text { Would you like to learn more about internal } \\
\text { audit? }\end{array}$} & No & 7 \\
\cline { 2 - 3 } & Yes & 0 \\
\cline { 2 - 3 } & I don't know & 0 \\
\hline
\end{tabular}

Source: Author's own study.

As many as 51 respondents believed that they had sufficient knowledge of internal audit, 2 admitted to knowing little about it, and 4 did not give an answer to this question at all. It is, therefore, hardly surprising that almost all respondents (50) expressed their disinterest in learning more about the goals and working of internal audit.

The respondents were also asked to pick a phrase(s) that in their mind best characterised the way internal audit functioned in their organisations (Table 4).

Table 4. How would you describe internal audit in your organisation?

\begin{tabular}{|l|c|}
\hline \multicolumn{1}{|c|}{ Internal audit... } & Total \\
\hline is a policing activity & 57 \\
\hline is only focused on finding irregularities & 54 \\
\hline does not command respect for itself & 54 \\
\hline is an exclusively control function & 52 \\
\hline deals with the financial aspects of organisation's activities & 51 \\
\hline does not add value to the organisation & 51 \\
\hline has nothing but disadvantages & 47 \\
\hline has both consulting and control functions & 11 \\
\hline helps the organisation attain its goals & 4 \\
\hline improves the operation of the organisation & 3 \\
\hline adds value to the organisation & 2 \\
\hline has an exclusively consulting function & 2 \\
\hline identifies threats and opportunities in the organisation's environment & 1 \\
\hline I don't know & 0 \\
\hline No answer & 0 \\
\hline
\end{tabular}

Source: Author's own study. 
The respondents were unanimous in associating internal audit in their organisations with a policing function enforcing rules and standards. It was the only question on which such complete unanimity was observed. As it appears, none of the survey participants was aware that internal audit evolved in time and also included the consulting function; consequently, they stereotyped it as a control activity it had been early on. Only 3 respondents were aware that one of its goals was to support organisations in improving their performance and attaining their objectives in an effective and cost-effective manner. Worse still, as many as 54 respondents admitted to having no respect for internal audit (and probably also to internal auditors). The cause of this disrespect is not clear, but it certainly deserves to be thoroughly investigated because of its likely impact on the perception of internal audit effectiveness.

In keeping with Weizenbaum's (2008) statement that "almost everything we know, including serious science, is based on a metaphor" and Morgan's (1997) observation that metaphors are "thinking images" that help analyse and understand reality, the respondents were requested to indicate one or more metaphors, or use their own one, ${ }^{4}$ that most adequately described internal auditors (Table 5).

Table 5. Which of the following metaphors best describe the internal auditor?*

\begin{tabular}{|l|c|}
\hline \multicolumn{1}{|c|}{ Answer } & Total \\
\hline Policeman & 57 \\
\hline Watchdog & 4 \\
\hline Guardian angel & 0 \\
\hline Sage & 0 \\
\hline Navigator & 0 \\
\hline I don't know & 0 \\
\hline No answer & 0 \\
\hline
\end{tabular}

* multiple-choice question

Source: Author's own study.

Almost all the respondents chose the metaphor of a policeman, consistent with the policing function of internal audit that they indicated before. Four respondents associated internal auditors with watchdogs, apparently perceiving some advantages in having them in the organization. Even so, their choice too was strongly influenced by the image of internal auditors as those who control others. None of the respondents viewed them as "guardian angels", "sages", or "navigators", meaning that they did not realize their role as the providers of assurance services. Summing up, for all respondents in the survey, internal audit was an investigative activity focused on singling out those who cross the lines.

In order to find out how much the respondents knew about the internal auditor's work, they were asked to indicate tasks performed by internal auditors. To complicate this exercise, they were provided with a list containing true and false answers (Table 6).

\footnotetext{
${ }^{4}$ This option was not exercised by any of the respondents.
} 
Pobrane z czasopisma Annales H - Oeconomia http://oeconomia.annales.umcs.pl

Data: 26/04/2023 16:35:49

AN INTERNAL AUDIT EXPECTATION GAP IN POLAND

Table 6. Is this a task of the internal auditor?

\begin{tabular}{|l|c|c|c|c|}
\hline \multicolumn{1}{|c|}{ Internal auditors... } & Yes & No & I don't know & No answer \\
\hline prevent and detect frauds & & & \\
\hline deal with organisations' finances & 56 & 1 & 0 & 0 \\
\hline support accounting processes & 49 & 8 & 0 & 0 \\
\hline audit financial statements & 49 & 8 & 0 & 0 \\
\hline assess organisation's progress against its goals & 49 & 8 & 0 & 0 \\
\hline develop internal rules & 49 & 8 & 0 & 0 \\
\hline prepare financial reports & 49 & 8 & 0 & 0 \\
\hline prepare financial or personnel plans & 47 & 10 & 0 & 0 \\
\hline conduct economic analyses & 39 & 10 & 8 & 0 \\
\hline plan budgets & 38 & 18 & 1 & 0 \\
\hline make cost calculations & 37 & 19 & 1 & 0 \\
\hline advise on tax issues & 36 & 19 & 2 & 0 \\
\hline make independent assessments of organisation's performance & 11 & 40 & 6 & 0 \\
\hline help an organisation to achieve its goals & 7 & 48 & 2 & 0 \\
\hline
\end{tabular}

Source: Author's own study.

Fifty-six respondents indicated that the focus of internal audit was on preventing and detecting frauds, a finding consistent with the image of internal audit as a policing function, and nearly as many (49) believed that its role was to keep organisational finances in order. Again, the respondents apparently missed the development of internal audit from a function targeting frauds and irregularities to one providing also consulting services and seeking ways to improve organisational processes. Their perception of internal audit proved once again to be very traditional and far from its modern-day reality.

The respondents were also asked about whether internal audit was beneficial for organisations and about their acceptance of this function (Table 7).

Table 7. What is your assessment and attitude towards internal audit?

\begin{tabular}{|l|l|r|}
\hline \multicolumn{1}{|c|}{ Questions } & \multicolumn{1}{c|}{ Answers } & Total \\
\hline \multirow{4}{*}{$\begin{array}{l}\text { Do you think your organisation benefits from } \\
\text { the internal audit function? }\end{array}$} & No & 47 \\
\cline { 2 - 3 } & I don't know & 6 \\
\cline { 2 - 3 } & Yes & 4 \\
\cline { 2 - 3 } & No answer & 40 \\
\hline \multirow{4}{*}{$\begin{array}{l}\text { Do you accept the presence of internal audit } \\
\text { in your organisation? }\end{array}$} & No & 13 \\
\cline { 2 - 3 } & Yes & 4 \\
\cline { 2 - 3 } & I don't know & 0 \\
\cline { 2 - 3 } & No answer & 4 \\
\hline
\end{tabular}

Source: Author's own study.

Forty-seven respondents did not find internal audit of much use and only around one-fourth (13) accepted its presence in their organisations. Even fewer (4 managers/ executives) indicated that their organisations benefitted from having their own in- 
ternal audit department. Among the non-auditors and audit committee members, not a single respondent thought that internal audit could add value to their organisation nor accepted its presence. Summing up, the respondents' attitude to internal audit was generally unfavourable, likewise their opinions on its usefulness.

Two questions in the survey were asked to determine whether, in the respondents' opinion, stakeholders' incomprehension of the internal audit goals could contribute to the emergence of an internal audit gap and whose problem it was (Table 8).

Table 8. What do you think causes internal audit and who is it a problem for?

\begin{tabular}{|l|l|r|}
\hline \multicolumn{1}{|c|}{ Questions } & \multicolumn{1}{c|}{ Answers } & Total \\
\hline \multirow{3}{*}{$\begin{array}{l}\text { Is stakeholders' incomprehension of internal } \\
\text { audit a critical factor in the emergence of the } \\
\text { expectation gap? }\end{array}$} & Yes & 41 \\
\cline { 2 - 3 } & No & 16 \\
\cline { 2 - 3 } & No answer & 0 \\
\cline { 2 - 3 } & I don't know & 53 \\
\hline \multirow{4}{*}{$\begin{array}{l}\text { Who is the internal audit expectation gap } \\
\text { a problem for? }\end{array}$} & Internal auditors & 4 \\
\cline { 2 - 3 } & I don't know & 0 \\
\cline { 2 - 3 } & Internal auditors and other staff & 0 \\
\cline { 2 - 3 } & All internal audit stakeholders & 0 \\
\cline { 2 - 3 } & Internal auditors and managers/executives & 0 \\
\cline { 2 - 3 } & No answer & \\
\hline
\end{tabular}

Source: Author's own study.

Forty-one the respondents agreed that expectations formulated by internal audit stakeholders not understanding the function goals might critically contribute to the emergence of the audit expectation gap, while 16 did not find it that the mismatch could be a likely reason for it. The bulk of the respondents (53) who answered the question about who should deal with the expectation gap problem pointed to internal auditors (only 4 had no opinion on this and chose "I don't know").

The respondents were also asked questions about their expectations about internal audits, the auditors' attitude to them, and whether they saw a relationship between their expectations and internal audit effectiveness (Table 9).

Table 9. What is your view on the relationship between internal audit stakeholders' expectations and the function's effectiveness?

\begin{tabular}{|c|c|c|}
\hline Questions & Answers & Total \\
\hline \multirow{4}{*}{$\begin{array}{l}\text { Do you think your expectations have no } \\
\text { influence on internal audit effectiveness? }\end{array}$} & Yes & 46 \\
\hline & No & 11 \\
\hline & I don't know & 0 \\
\hline & No answer & 0 \\
\hline \multirow{4}{*}{$\begin{array}{l}\text { Do internal auditors try to meet your } \\
\text { expectations? }\end{array}$} & No & 54 \\
\hline & Yes & 3 \\
\hline & I don't know & 0 \\
\hline & No answer & 0 \\
\hline
\end{tabular}

Source: Author's own study. 
The majority of the respondents (46) expressed a disbelief that their expectations could have any influence on internal audit effectiveness, whereas 11 thought that what they expected had some effect on it. At the same time, as many as 54 respondents were disappointed with internal auditors' response to their expectations, with only 3 being satisfied with it.

Table 10 contains respondents' answers to the question what they would like internal auditors to be.

Table 10. What are your expectations about internal auditors?

\begin{tabular}{|l|c|c|c|}
\hline \multicolumn{1}{|c|}{ Expectations } & Total & I don't know & No answer \\
\hline No internal auditors in the organization & 52 & 0 & 0 \\
\hline "More humane" internal auditors & 27 & 0 & 0 \\
\hline Internal auditors supporting change processes in the organisation & 14 & 0 & 0 \\
\hline Competent internal auditors with good interpersonal skills & 12 & 0 & 0 \\
\hline Inactive internal auditors & 12 & 0 & 0 \\
\hline Internal auditors adding value to the organisation & 3 & 0 & 0 \\
\hline I don't know & 2 & 0 & 0 \\
\hline No answer & 0 & 0 & 0 \\
\hline
\end{tabular}

Source: Author's own study.

Almost all respondents (52) wanted internal auditors to be removed from their organisations, thus, expressing their negative attitude to the internal audit function. However, the fact that around half of them wished that internal auditors would be "more humane" implied that they would accept their presence in the organisation under certain conditions.

\section{Discussion}

The expectation gap is a serious problem affecting the internal audit function. The excessive or illegitimate expectations of the stakeholders and the internal auditors' inability to fulfil those that can make their work more effective cause a climate of distrust to build up around the role and value of internal audit in the organisation.

The survey of internal audit stakeholders provided the following key observations:

- the majority of the respondents were unaware of the contemporary role and goals of internal audit; consequently, what they expected of it was inconsistent with what it could offer,

- the respondents had very limited knowledge of internal audit and could not properly describe its role and goals,

- the respondents appeared to be unaware of the evolution of internal audit from a function focused on detecting frauds and loopholes in organisations' procedures to an activity supporting the analysis of business and organisation- 
al risks, overseeing the infallibility of the internal control mechanisms, and helping to improve organisations' performance through professional advice and consultation,

- almost all respondents associated internal audit with its early function, i.e. the prevention and detection of frauds and irregularities in financial statements produced by government agencies and organisations,

- the misperception of the internal audit function prevented the respondents from accepting internal auditors as partners and a vital element of the mechanism helping organisations become competitive and successful,

- the majority of the respondents believed that internal auditors did not take account of their expectations in planning their activities. Whether the belief adds to the negative reputation of the internal audit profession and low evaluations of internal audits requires further research.

The above observations indicate that more empirical research on the internal audit expectation gap is necessary to improve the knowledge of its causes and impacts and to create effective measures for dealing with insufficient awareness and misperceptions of the role of internal audit.

The results of the author's pilot study presented in the article have both theoretical and practical implications. Regarding the former, they expand the existing knowledge of internal audit in Poland, bring attention to how the internal audit expectation gap affects its perception, and offer a promising foothold for future explorations in this field. They may also encourage researchers to adopt different perspectives and test new concepts with larger and more diverse groups of respondents to ensure reliable inference. The development of research into the internal audit expectation gap in Poland seems important given the lack of Polish investigations, markedly contrasting with the abundance of international works on this subject.

The main practical implication of the study is that it may raise internal auditors' awareness that the expectation gap is not a theoretical construct but an inseparable aspect of their daily work that influences the perception of their effectiveness and consequently affects the course of their careers.

\section{Limitations and conclusions}

The pilot study has several limitations related to the research method adopted. Firstly, as the questionnaires were completed online by unsupervised respondents, there is a risk that they could misunderstand or misinterpret the questions. Secondly, while online surveys allow an idea of the phenomenon under consideration, they are only a means for compiling respondents' subjective opinions that must be supported by other data sources to have a full picture of it. Thirdly, the sample of internal audit stakeholders was selected in a non-representative manner and was rather small because many potential respondents refused to participate in the survey. 
These limitations aside, the results of the study deepen the insight into the contemporary aspects and problems of internal audit effectiveness. They allow better understanding of how its perception is affected by the internal audit expectation gap, which makes them useful for internal audit theoreticians and practitioners alike.

\section{References}

Ahmad, Z., \& Taylor, D. (2009). Commitment to Independence by Internal Auditors: The Effects of Role Ambiguity and Role Conflict. Managerial Auditing Journal, 24(9), 899-925. https://doi.org/10.1108/02686900910994827

Arena, M., \& Sarens, G. (2015). Editorial: Internal Auditing: Creating Stepping Stones for the Future. International Journal of Auditing, 19(3), 131-133. https://doi.org/10.1111/ijau.12053

Azham, A., Teck Heang, L., Mohamad, R., \& Ojo, M. (2008). Internship and Audit Expectation Gap Among Undergraduate Students in Universiti Utara Malaysia. Journal of Financial Reporting and Accounting, 6(1), 55-74. https://doi.org/10.1108/19852510880000635

Bednarek, P. (2016). Wpływ kierownictwa wyższego szczebla i komitetu audytu na wartość dodaną audytu wewnętrznego. Studia Ekonomiczne Uniwersytetu Ekonomicznego w Katowicach, 268, 34-42.

Carcello, J.V., Eulerich, M., Masli, A., \& Wood, D.A. (2018). The Value to Management of Using the Internal Audit Function as a Management Training Ground. Accounting Horizons, 32(2), 121-140. https://doi.org/10.2308/acch-52046

Cohen, A., \& Sayag, G. (2010). The Effectiveness of Internal Auditing: An Empirical Examination of its Determinants in Israeli Organisations. Australian Accounting Review, 20(3), 296-307. https://doi.org/10.1111/j.1835-2561.2010.00092.x

D’Onza, G., \& Sarens, G. (2018). Factors That Enhance the Quality of the Relationships Between Internal Auditors and Auditees: Evidence from Italian Companies. International Journal of Auditing, 22(1), 1-12. https://doi.org/10.1111/ijau.12100

Dewing, I., \& Russell, P. (2002). UK Fund Managers, Audit Regulation and the New Accountancy Foundation - Towards a Narrowing of the Audit Expectations Gap? Managerial Auditing Journal, 17(9), 537-545. https://doi.org/10.1108/02686900210447533

Dobroţeanu, L., Dobroțeanu, C.L., \& Ciolpan, D. (2009). A semiologic Approach to Audit Expectations. Annals of the University of Oradea. Economic Science Series, 18(3).

Enes, E.F., de Almeida, B.J., da Silva A., Carvalho, F.P., \& Simões, J.M. (2016). Education as a Contribution to Reduce the Audit Expectation Gap: The Portuguese Case. Tékhne - Review of Applied Management Studies, 14(1).

Filipczyk-Gałązka, A. (1994). Problem oczekiwań szkolnych uczniów w świetle różnych teorii psychologicznych. Chowanna, 1, 20-31.

Frigo, M. (2002). A Balanced Scorecard Framework for Internal Auditing Departments. Altamonte Springs: The IIA Research Foundation.

Grzesiak, L. (2019). Myths on Internal Auditing. Przedsiębiorczość i Zarządzanie, 20(6/1), 421-434.

Grzesiak, L. (2020). Kapitał ludzki a skuteczność audytu wewnętrznego. PhD dissertation.

Humphrey, C., Moizer, P., \& Turley, S. (1993). The Audit Expectation Gap in Britain: An Empirical Investigation. Accounting and Business Research, 23(91), 395-411.

https://doi.org/10.1080/00014788.1993.9729907

IIA (The Institute of Internal Auditors). (n.d.). Internal Auditing. Adding Value Across the Board. Retrieved from https://na.theiia.org/about-ia/PublicDocuments/Internal_Auditing-Adding_Value_Across_the Board.pdf 
IIA. (2011). A Call to Action: Stakeholders'Perspectives on Internal Auditing. Retrieved from https://www. iia.nl/SiteFiles/IIA_leden/CBOK\%20Stakeholders\%20USA\%20only\%20.pdf

International Standards for the Professional Practice of Internal Auditing. (2016). Florida: IIA.

Koh, H., \& Woo, E. (1998). The Expectation Gap in Auditing. Managerial Auditing Journal, 13(3), 147-154. https://doi.org/10.1108/02686909810208038

Kozielecki, J. (1997). Koncepcje psychologiczne człowieka. Warszawa: Żak.

KPMG. (2016). Quality Assessment of Internal Audit. Retrieved from https://assets.kpmg.com/content/ $\mathrm{dam} / \mathrm{kpmg} / \mathrm{ch} / \mathrm{pdf} / \mathrm{ch}$-quality-assessment-internal-auditing-en.pdf

Lenz, R., Sarens, G., \& Hoos, F. (2017). Internal Audit Effectiveness: Multiple Case Study Research Involving Chief Audit Executives and Senior Management. EDPACS, 55(1), 1-17. Retrieved from https:// www.researchgate.net/publication/312045439_Internal_Audit_Effectiveness_Multiple_Case_Study_ Research_Involving_Chief_Audit_Executives_and_Senior_Management/link/5a29bfbeaca2728e05dae913/download

Lenz, R., Sarens, G., \& Jeppesen, K.K. (2018). In Search of a Measure of Effectiveness for Internal Audit Functions: An Institutional Perspective. EDPACS, 58(2), 1-36. Retrieved from https://www. researchgate.net/publication/327061036_In_Search_of_a_Measure_of_Effectiveness_for_Internal_ Audit_Functions_An_Institutional_Perspective

Meigs, W., Whittington, O., Meigs R., \& Lam, W. (1983). Principles of Auditing. Homewood: Richard D. Irwin.

Moeller, R. (2018). Nowoczesny audyt wewnętrzny. Warszawa: Nieoczywiste.

Morgan, G. (1997). Obrazy organizacji. Warszawa: PWN.

Nowak, S. (2007). Metodologia badań spolecznych. Warszawa: PWN.

Porter, B. (1990). The Audit Expectation-Performance Gap - an Empirical Investigation. Perth: AAANZ Conference.

Porter, B. (1993). An Empirical Study of the Audit Expectation-Performance Gap. Accounting and Business Research, 24(93), 49-68. https://doi.org/10.1080/00014788.1993.9729463

PwC. (2016). State of the Internal Audit Profession Study Leadership Matters: Advancing Toward True North as Stakeholders Expect More. Retrieved from https://www.pwc.pl/pl/pdf/2016-state-of-the-internal-audit-profession.pdf

Ruhnke, K., \& Schmidt, M. (2014). The Audit Expectation Gap: Existence, Causes, and the Impact of Changes. Accounting and Business Research, 44(5), 572-601.

https://doi.org/10.1080/00014788.2014.929519

Skoczylas-Tworek, A. (2014). Audyt we współczesnej gospodarce rynkowej. Łódź: UŁ.

Weizenbaum, J. (2008). Moglibyśmy mieć raj. Forum. 